University of Louisville

ThinkIR: The University of Louisville's Institutional Repository

Electronic Theses and Dissertations

8-1948

\title{
A study of the social adjustment of schizophrenic patients following electroshock therapy.
}

Lillian D. Morgan

University of Louisville

Follow this and additional works at: https://ir.library.louisville.edu/etd

Part of the Social Work Commons

\section{Recommended Citation}

Morgan, Lillian D., "A study of the social adjustment of schizophrenic patients following electroshock therapy." (1948). Electronic Theses and Dissertations. Paper 2013.

https://doi.org/10.18297/etd/2013

This Master's Thesis is brought to you for free and open access by ThinkIR: The University of Louisville's Institutional Repository. It has been accepted for inclusion in Electronic Theses and Dissertations by an authorized administrator of ThinkIR: The University of Louisville's Institutional Repository. This title appears here courtesy of the author, who has retained all other copyrights. For more information, please contact thinkir@louisville.edu. 


\title{
UNIVERSITY OF LOUISVILLE
}

A STUDY OF THE SOCIAI ADJUSTMENT OF SCHIZOPHRENIC PATIENTS FOLIOWING ELECTROSHOCK THERAPY

\author{
A Dissertation \\ Submitted to the Faculty \\ Of the Raymond A. Kent School of Social Work \\ In Partial Fulfillment of the \\ Requirements for the Degree \\ Of Master of Science in Social Work
}

\author{
by \\ Lilliam D. Morgan \\ 1948
}


This PDF document is a scanned copy of a paper manuscript housed in the University of Louisville (UofL) Libraries. The quality of this reproduction is greatly dependent upon the condition of the original paper copy. Indistinct print and poor quality illustrations are a direct reflection of the quality of materials that are available for scanning. The UofL Libraries greatly appreciates any better copies that can be made available for replacement scans. 
NAIE OF STUDENT: Lillian D. Morgan

TITLE OF THESIS: A Study of the Social Adjustment of Schizophrenic Patients Following Electroshock Therapy

APPROVED BY READING COMTITTEE COIPOSED

OF THE FOLLOWING MERBERS:

Howell V. Williams

Sylvia R. Jacobson

NARE OF DEAN: Howell V. Williams

DATE: August 24,1948 


\section{ACKNOWLEDGE FENT}

The author wishes to acknowledge to the staff of the Louisville General Hospital for placing material at her disposal and for the kind assistance given by members of the staff of the Psychiatry Department, and particularly to the patients who participated by giving personal information. 
TABLE OF CONLENTS

PAGE

INTRODUCTION . . . . . . . . . . . 2 CHAPTER

I. CASE SUIDARIES OF THREE PATIEITS IN LNVELS 1 AND 2 . . . . . . . 8

II. CASE SUNARIES OF TWO PATIENTS

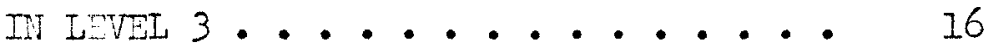

III. CASE SUMARIES OF TWO PATIENTS IN LEVEL 4 . . . . . . . 22

IV. CASE SUMMARIES OF THREE PATIENTS IN LEVELS 6 AND 7 . . . . . . . 29

V. DISCUSSION AND CONCLUSIONS . . . . 38 APPEIIDIX . . . . . . . . . 52 BIBLIOGRAPHY ............ 55 
INTRODUCTION 
Purpose of study

The purpose of this study is to inquire into the sccial adjustment of patients admitted to the Louisville General Hospital in 1946, diagnosed as schizophrenic, treated there with electroshock therapy and subsequently discharged to their homes or to the Central state Hospital.

Schizophrenia, as we know, is considered one of the most serious of personality disturbances and accounts for a high proportion of the admissions to mental hospitals. There are over 20,000 schizophrenics entering mental hospitals in the United States yearly. 1 Prior to the use of convulsive therapy the prognosis for schizophrenic patients was regarded as poor, and no methods of treatment had ever resulted in much success. About ten to fifteen per cent of hospitalized cases of schizophrenia made spontaneous social recoveries, that is, were able to leave the hospital and more or less maintain themselves even though some mental symptoms were still present. 2

There have been a number of studies made on the results of electroshock therapy with varying conclusions as to the benefits of the treatment. Remission rates vary in these studies from 40 per cent, in a study which contained a large number of Iong-standing cases, to 67.4 percent in cases of short duration. 3 It is thought that the differing

\footnotetext{
IEdward Weiss and 0. Spurgeon English, Psychomatic Medicine, (Philadelphia and London: W.E. Saunders Company, 1943), p. 38.

2Lawson G. Lowry, Psychiatry for Social Workers, (New York: Columbia University Press, 1946), p. 11.

3. B. Kalinowsky and H.J. Worthing, "Results with Electric Convulsive Therapy in 200 Cases of Schizophrenia," Psychiatric Quarterly, XVII (1943), $144-148$.
} 
conclusions have been due to the differences in approach, variations in treatment methods, and differences in the length of time elapsing between the treatment and the follow-up study. However, it appears that electroshock therapy has increased the number of remissions, decreased the length of hospital stay and made many patients more comfortable who have had to remain in the hospital.

The follow-up studies which have been published have had to do primarily with comparison of different methods of treatment and with the different types of schizophrenia. Opinions differ on the importance of some factors, such as heredity, age and sex but there is complete agreement among all workers that there is an inverse ratio between the duration of the illness and recovery. The constitutional and personality make-up, the social, sexual, and personality ajjustments before onset of illness are considered by many workers to be of some importance. I The success of the treatment is gauged by the adjustment the patient is able to make after treatment.

In this study which inquires into the social adjustment of schizophrenic patients admitted to the Louisville General Hospital in 1946 and treated there with electroshock therapy, a total of twenty-one cases $^{2}$ were reviewed and ten, consiciered to be representative are presented. The Table of Adjustment of Thomas A.C. Rennie3 as revised for the use of the Temporary Commission on State Hospital Problems 4 will be used to

$I_{\text {L.B. Kalinowsky and P.H. Hoch, Shock Treatments and Other Somatic }}$ Procedures in Psychiatry, (New York: Grune \& Stratton, 1946), pp. 84-86.

2 These cases were taken from the records of the Psychiatry Department of Louisville General Hospital, Louisville, Kentucky.

3T.A.C. Rennie, "Follow-up Study of 500 Patients with Schizophrenia Adnitted to the Fospital from 1913 to 1923". Archives of Neurology and Psychiatry, XIII (1942) 877-891.

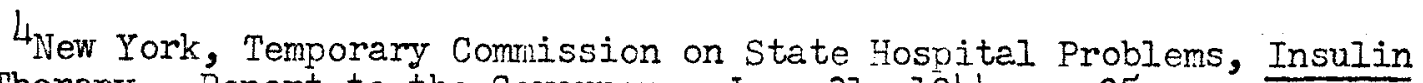
Shock Therapy. Report to the Governor. June 31, 1944. p. 25. 
differentiate the several levels of social adjustment attained by these patients after treatment and described here. The table arranged by the Temporary Comission is as follows:

Table of Adjustment:

Level 1 - Those patients who developed beyond their pre-psychotic level and who at the tine of our study were getting along well and better than before their illness in their social and familial relationships.

Level 2 - Those patients who were doing well and at least as well as they did before their iliness.

Level 3 - Those patients who were able to get along in their family position and in their employment with some slight degree of protection and who given this moderate help were able to lead a substantially normal existance.

Level 4 - Those patients who were at home but made no contribution to family or social life. They were family invalids, vegetative, harmless, without dangerous impulses but too disorganized to fix attention on any task, or disturbed to the extent of justifying hospitalization but being cared for at home by family members.

Level 5 - Those patients who were productive hospital invalids, able to work consistently, performing unsupervised work of high grade, calling for some initiative.

Level 6 - Those patients who were less productive hospital invalids, unable to do more than engage in simple activity, such as routine help on the ward.

Level 7 - Those patients who were deteriorated hospital invalids, comprising the most helpless of all patients, and those most disturbed requiring constant care and attention.

Method of Study

The cases selected for study were taken from the hospital record of the total number of schizophrenic patients treated with electroshock therapy on the Psychiatry Warcs of the Louisville General Hospital in 1946. The psychiatric charts of thirty-two patients were reviewed to select only those patients who were residents of Jefferson County, Kentucky and could be located for follow-up study. In addition to the cases screened out by this method it was necessary to discard others because of lack of sufficient information for such a study. A total of twenty-one cases remained after 
- the screening process was completed.

In each of the twenty-one cases the psychiatric chart was again studied and information relative to the adjustment previous to illness, length of hospital stay, diagnosis as to sub-type of schizophrenia, prognosis and disposition was carefully noted on individual schedules.

The charts of some of the patients contained information as to their adjustment approximately a year after hospitalization. This information had been secured by the medical student who was assigned to the case while the patient was in the rospital and was obtained by a home visit as a part of the medical student's assignment. Where there was such information, it was carefully noted on the individual schedules also.

After the compilation of all the known facts in the psychiatric chart, a study was made by the writer of the present situation of each of the twenty-one patients selected for study. This portion of the study was done by home visits to those not hospitalized, personal interviews in the hospital with the patients or members of the hospital staff for those patients who were in the hospital, and study of the out-Patient Clinic records for those who had kept up their contacts there. This follow-up study was done approximately two years after the hospitalization in 1946. It should be noted that the time elapsing between the hospitalization and the follow-up study varied with the different patients as not all of them were in the hospital at the same time.

These cases were studied for an evaluation of the social adjustment of the patients. It should be noted that the phrase social adjustment, as used here, includes interpersonal relationships in the parental home, sexual or marital adjustrnent, and industrial and community adjustments. In order to arrive at the level of adjustment achieved after treatment as 
compared with earljer adjustment and in order to obtain a picture of improvement, or lack of improvement, it is obvious that it is necessary to consider the same factors in adjustment prior to illness. In each of the twenty-one cases a comparison of the pre-illness and post-treatment adjustment was drawn using Rennie's Table of Adjustment as revised. Cases Presented

of the twenty-one cases worked up, ten considered representative are presented here. Similar information was obtained on all of the cases but is described in detail in the ten cases which are summarized below. The cases presented included eight adults, six women anc two men, and two adolescent boys.

The cases were selected from the levels of adjustment as determined by the writer in accorcance with the described criteria. One case was selected from Level 1, which represents the highest level of adjustment, a level in which the patient is getting along better than before his illness. Two cases were selected from Level 2, the level at winich the patient is doing as well as before illness. Two cases were selected from Level 3, the level at which the patient is getting along at home but with slight protection. Two cases were selected from Level 4 , the level of the family invalid. There were no patients among the twenty-one studied who could be considered productive hospital invalids, which would have placed them in Level 5. One case each was selected from Levels 6 and 7, the respective levels of the less productive hospital invalid and the deteriorated invalid.

The diagnosis on the demonstrated cases included the following sub-types of schizophrenia: paranoid, catatonic, hebephrenic, and mixed. 
CHAPTER I

CASE SUMARIES OT THREE PATIENTS IN LEVELS 1 AND 2 
CASE I - Mrs. Hoover ${ }^{1}$

\section{THE PATIENT:}

Mrs. Hoover, a white, widowed female, thirty-six years of age, was admitted to the Psychiatry Ward on March 26, 1946, and diagnosed as Schizophrenia, hebephrenic type. The history given by her family was that she had had many complaints and several operations, including an ovarectomy, since the death of her husband six years previously. Recently she had begun to have hallucinations and to make silly, inappropriate responses. She was treated with electroshock therapy at Louisville General Hospital until May 9, 1946, and then transferred to Central State Hospital for further treatment. Prognosis was guarded. She was released from Central State Hospital on parole status in July, 1946, as improved, and was discharged a year later.

PARENTAL HORE AND EARIY ADUUSTRETIT:

Mrs. Hoover was the third of four children. Her parents and three siblings were living and well at the time of her admission to the hospital. Birth and early development were normal. There were close family ties and the children were reared in a strict, religious environment. The family had average middle-class advantages and Mrs. Hoover had completed her first year of college when she married. She was described as a friencly, out-going person who made friends easily. Her chief interests were concerned with church activities and her Sunday School class.

SEXUAL OR MARITAL ADJUSTIENT:

Mrs. Hoover was happy in her marriage and with her two daughters. After her husband's death the family was supported by a Government pension which was barely adequate for their needs. In 1941, Mrs. Hoover had a series of illnesses and operations. In 1942, she was admitted to the Psychiatry Ward and treated for a period of nine weeks for bromide psychosis. She had feelings of frustration and became sexually promiscuous, with resulting intense feelings of guilt. Her attitude toward her mother became one of resentment but she was still fond of and friendly toward other members of her family.

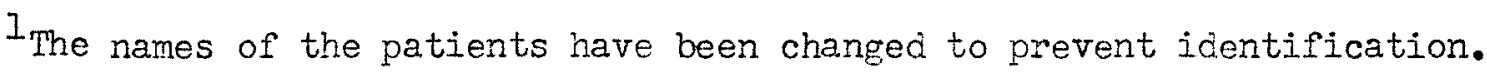


Shortly before Mrs. Hoover's admission to the hospital, her eighteen year old daughter married and her husband came to live in the home with them. Mrs. Hoover and her son-in-law were antagonistic from the first and had frequent quarrels.

\section{INDUSTRIAL AND COMMUNTTY ADUUSTMENTS:}

Mrs. Hoover had no employment history. Her activities outside the home were confined to church and Sunday School and neighborhood contacts. She visited her family frequently and was on good terms with all of them until after her husband's death, when she became resentful toward her mother.

\section{POST-TREATHENT ADJUSTTENTS:}

Mrs. Hoover was followed up continuously in the Out-Patient Clinic. She came in at irregular intervals for a total of twelve interviews during the two years following her hospitalization. One year after treatment a home visit was made by a medical student and her recovery was considered amazing. Her married daughter had moved out of the home and Mrs. Hoover was no longer so antagonistic toward her son-in-law. She had resumed teaching her sunday School class and was again active in church work. Her single daughter, who had been taken out of school when her mother first came home, was re-entering in the fall. Mrs. Hoover was planning to get a job.

In an interview in the Out-Patient Clinic, approximately one month before this study was made, Mrs. Hoover stated that she was considering marrying again. She hac taken a job in a nearby tourist camp and found the work stimulating and enjoyable.

COMIENT:

This is a case of a woman whose illness probably started when her husband died. Until his death she had led a sheltered and protected life and had faced few unpleasant realities. When she dealt with her feelings of frustration by sexual promiscuity her religious upbringing caused intense guilt feelings which she could not handle. Her daughter's marriage may have precipitated her illness by reactivating her own sexual conflicts.

Some authorities look on the psychotic reactions of the schizophrenic as a cure for otherwise insoluble conflicts. ${ }^{1}$ This could be true in Irs. Hoover's case and her use of bromides was probably an attempt on her part to escape from the realities of her situation.

\footnotetext{
Lowry, op.cit., p. II
} 
The use of psychotherapy has been a debatable question but no study is available that proves the necessity of psychotherapy by comparing results in patients who received psychotherapy with those who did not. At present no generalization as to the benefits of psychotherapy is possible; each case must be individually appraised. Most workers agree, however, that where psychotherapy is indicated, it should follow shock treatment rather than run concurrently with it. The patient is often fortified wi.th the shock treatment to face the dissection of overwhelming conflicts. 1

The presence of precipitating causes is generally considered a favorable prognostic sign and in Mrs. Hoover's case there were precipitating causes. The fact that she had a somewhat extroverted personality make-up was also favorable for recovery.

Mrs. Hoover was classified in Level $I$ in the Table of Adjustment. Her post-treatment social adjustment was considered better than her preillness adjustment because she had faced the realities in her situation and was dealing with them. She had gained some insight into her behavior and had sought psychiatric help when she felt she needed it. She was facing the future with plans for remarriage and was supplementing the government pension by gainful and pleasant employment.

\section{CASE 2 - Mrs. Cain}

THE PATIENT:

Mrs. Cain, a white, twenty-six year old, married female with two pre-school children, was admitted to the Psychiatry ward on

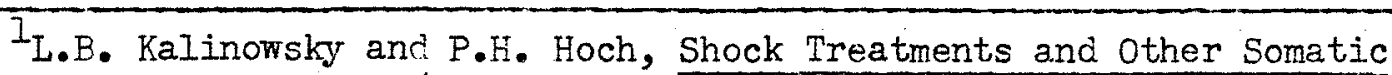
Procedures in Psychiatry, (New York: Grune and Stratton, 1946) p. 24I 
August 8, 1946. Her symptoms were suspiciousness, distrust, irritability and growing unconcern with the daily duties of mother and wife. She had somatic complaints and admitted auditory and visual hallucinations. Her history revealed two nervous breakdowns, in 1940 and 1944 . She was treated with electroshock therapy until she was signed out by her husband on September 17, 1946. When signed out her behavior was described as "manic". Diagnosis was Schizophrenia, mixed type. Prognosis was "fair".

PARENTAL HONE AND FARLY ADJUSTMENTS:

Mrs. Cain was the youngest of three daughters reared in a family of marginal economic standards. Her parents were know to several social agencies during periods of financial stress. In the family history, there was a paternal aunt who had been institutionalized for mental illness and another aunt who had had several nervous breakdowns. As a child, Mrs. Cain led a sheltered and protected life. She was describec as a very shy child who had feelings of inferiority and was subject to temper tantrums. She had gooc health, made average grades in school and completed the ninth grade. Family ties were close but there was no history of unusual attachments.

SEXUAL OR MARITAL ADJUSTMENTS:

Mrs. Cain married against the wishes of her family and there was consicerable friction between her, her husband, and her family. When she became pregnant she and her husband decided on an abortion. Following the abortion, in 1940, Mrs. Cain had a nervous breakdown but no history could be secured of her reactions at that time, except that of nervous irritability and guilt feelings.

In 1944, Mrs. Cain gave birth to a child and again hac attacks of nervousness which were centered around guilt feelings about the abortion. She had frightening dreams, was afraid to be alone and was suspicious of her family. When her second child was born she apparently made a normal recovery but it was shortly after the child's birth that her symptoms started. Approximately five weeks before admission to the hospital she began to show the symptoms previously mentioned.

\section{INDUSTRIAL AND COMUNITY ADJUSTMENTS:}

Prior to her illness Mrs. Cain had no employment record. She performed her household cuties adequately, doing her ow housework and taking care of her children. She had no outside interests nor hobbies, had little social life other than contacts with relatives. Her favorite recreation was reading.

POST-TREATIENT ADUUSTIENTS:

Mrs. Cain did not return for Out-Patient treatment but was followed up routinely a year after discharge by a medical student. She was apparently making a fair adjustment, was caring for her children and performing her household duties adequately. Her family thought she was acting normally although she was not getting along well with her husband. 
She still had no outside interests, few social contacts and was somewhat of a "worrier". Two years after the study hospitalization the writer made a follow-up home visit. Mrs. Cain had divorced her husband and was employed in a textile mill. Her mother had moved in with her and was taking care of the chilcren and doing the house work. Mrs. Cain said she was happy and had stopped most of her worrying since she was divorced. She felt that she should have returned to the out-Patient Clinic but had not had time.

COMNENT:

Mrs. Cain was classified in Level 2 (doing as well as before illness), although she thought she was happier and worried less than before. It seems likely that her unhappiness in her marriage was due in part to her feelings of guilt over marrying against her parent's wishes, and the intensification of these and other feelings following the abortion. After her divorce, when her mother had assumed Mrs. Cain's responsibilities of motherhood, she could return to the safe position of childlike dependency on the mother. In a less protected environment she would probably be unable to carry on.

It is unfortunate that professional information was not obtainable concerning the two previous break-downs. It is not easy to fix reliably the duration of psychoses in many patients. Dr. Kalinowsky stated:

Insidious development is not uncommon and before shock treatment was introduced it had been observed that in a considerable number of cases the schizophrenic psychosis did not develop progressively, as is customary in the majority of patients, but rather occurred in successive episodes similar to the manic-depressive psychoses. This was demonstrated particularly in the manic forms of schizophrenia where, instead of recovering from each attack and returning fully to the prepsychotic personality, as is the rule in the affective psychoses, the patient became progressively worse after each schizophrenic attack, and finally the psychosis persisted. The same development can now be observed in some shock-treated cases with episodic course. Statistics are not quite conclusive at present, but the clinical impression is that even though the majority of patients respond to treatment within each new attack, this response becomes progressively less complete; there is more and more "scar formation" in the sense of personality changes, particularly emotional flattening and other residues. ${ }^{1}$

\footnotetext{
$I_{\text {Kalinowsky and Hoch, op. cit. pp. } 85-86}$
} 
CASE 3 - Mrs. Echols

THE PATIENT:

Mrs. Echols, a thirty-two year old, married, negro female, was admitted to the ward on May 9, 1946, because of withdrawal symptoms. She refused to eat or talk except to accuse her family of trying to "drive her father crazy". On the ward, she said "her mind had snapped" following the death of her mother a year earlier. She was given the diagnosis of Schizophrenia, catatonic type and received a series of electroshock treatments. She was transferred to Central State Hospital for further treatment on May 23, 1946, from which hospital she was released on parole on June 28, 1946. She was cischarged a year later as improved.

PARTNTAL HOME AND EARLY ADJUSTMENTS::

Mrs. Echols was one of seventeen siblings reared by their parents in better-than-average economic circumstances. There were close family ties and Mrs. Echols was especially fond of her mother. The family history was negative for hereditary taints.

Mrs. Echols was described as a friendly person who made friends easily but led a quiet life. She made a good record in school and completed one year in high school. She enjoyed reading and sewing, attended church and Sunday School.

SEXUAL AND MARITAL ADJUSTMENTS:

At the age of ninteen; Mrs. Echols married a man of whom her family approved. Marital adjustment was satisfactory and her husband was devoted to her and their five daughters. There was some feeling of disappointment that all the children were girls but the children were wanted and treated with affection. Mr. Echols made a good living and was a devoted husband and father. He was sympathetic and understancing toward Mrs. Echols in her grief over her mother's death. He visited her frequently while she was in the hospital.

INDUSTRIAL AND COMUNITY ADJUSTMENTS:

Mrs. Echols had no employment history. She had few interests outside her family except for attending church fairly regularly. She had little time for social life and spent what leisure time she had in reading and sewing. POST-TREATMENT ADJUSTIENTS:

Two years after the hospitalization, Mrs. Echols was seen in a home visit by the writer. She was very proud of her six-months ola baby boy. Her house was neatly and attractively furnished and was kept very clean. The children looked healthy, wholesome and well-cared for. Mrs. Echols had attended Pre-Natal Clinic and had had a fairly easy delivery. She was 
still attending Clinic but her only complaint was persisting hypertension. She still had no outside interests but found her entire time was taken in caring for her family. She occasionally went riding with her husband and children. She appeared happy and content but did not like to discuss her illness. She revealed no insight into her illness.

COMENT:

Mrs. Echols was classified as functioning in Level 2. Her happy marital life was undoubtedly one of the important factors in her ability to maintain herself at her pre-psychotic level. The acute onset in a person not ordinarily a withdrawn type of personality, is generally considered a favorable prognostic sign.

The catatonics constitute about 25 per cent of the schizophrenic group and have by far the highest spontaneous recovery rate ( 25 to 30 per cent). It must be emphasized that this is a recovery without insight - at least beyond the merest notion that something has been wrong. 1 Catatonic schizophrenics usually respond well to electroshock therapy and prior to its use were subject to relapse and eventual deterioration. Data on relapse following shock therapy is not conclusive.

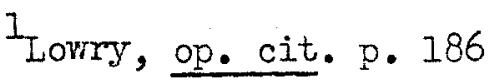


CHAPTER II

CASE SUMARIES OF TWO PATIENTS IN LEVEL 3 
THE PATIENT:

Mrs. Hale, a white married, twenty-five year old female, was admitted to the Psychiatry Ward on April 23, 1946, and diagnosed as Schizophrenia, Paranoid type. Her husband stated that in November of the preceding year she had become suspicious of him, accusing him of going with other women. This behavior continued for about three weeks, then Mrs. Hale began acting as usuel. A month previous to her admission to the hospital she began her accusations of infidelity against her husband again. She also began to have auditory hallucinations and the delusion that her mother was dead. She became progressively worse and was brought to the hospital. After a month at Louisville General Hospital with electroshock treatment, she was transferred to Central state Hospital for extended treatment. She was permitted to go home on parole status from Central State Fospital in September, 1946, and the parole was renewed in september, 1947.

\section{PARENTAL HONE AND EARLY ENVIRONITNT:}

Mrs. Hale was the youngest of nine children reared by their parents in a home of moderate means. There was no history of mental illness, although an aunt had suffered a nervous breakdown. Mrs. Hale was described by her family as a quiet, withdrawn child, never having close friends. She was sheltered and protected while growing up as she was a naturally timid child who withcrew even from her family, except her mother, with whom she was very close. She graduated from high school without having formed any close friendships. She remained at home until her marriage at the age of nineteen.

\section{SEXUAL OR MARITAL ADJUSTMENT:}

Mr. and Mrs. Hale were apparently greatly attached to each other, both were quiet and liked to stay at home so they had little social life. Both were fond of their only child, a daughter. Mr. Hale was the cominant member of the family and he made no effort to force Mrs. Hale to have outside interests. They had little to do with their neighbors but visited their families. Neither Mr. Hale nor the patient's family coulc uncierstand her sudden change toward her husband.

INDUSTRIAL AND COMUUNITY ADJUSTMENTS:

Mrs. Hale had no vocational interests; she had no hobbies nor recreational outlets. She did not participate in any neighborhood or church activities. Her social contacts were limited to her immediate family and. these contacts were infrequent. 
POST-TREATIENT ADJUSTTEMTS:

After release from Central State Hospital, Mrs. Hale returned to her home where she resumed her housework and care of her small daughter. Nine months later in a routine follow-up visit by a medical student he thought she was taking an interest in her housework and family but still showed a tendency to withdraw from outside contacts. Her husband thought she was about the same as before her illness, not interested in making friends or having any recreation.

Two years after her illness a home visit was mace by the writer. Mrs. Hale appeared apprehensive and uncommunicative and talked through the screen door. She stated that she was feeling well and was also doing a lot of housecleaning. She seemed suspicious and there was a noticeable twitching on the left side of her face. Her family felt that she was "rervous" and probably would need to return to the hosoital, for that reason they had her parole from Central State Hospital renewed rather than have her discharged from the rolls.

COMENT:

Mrs. Hale was classified in Level 3 since she was getting along in her family position and in a very protected environment. It appeared doubtful if she could continue indefinitely at home even with this protection. The gradual nature of onset in this case makes the prognosis poor, as does the fact that there were no apparent precipitating events. The patient's history, if more carefully taken, might have revealed other "flurries" or minor episodes; or the patient might have revealed intrapsychic stress not elicited by the examiner. The history indicates a pre-schizoid personality with the insidious development of psychosis, the duration of which it is difficult to fix reliably.

\section{CASE 5 - Miss Benton}

THE PATIENT:

Miss Benton, a negro female, aged twenty-six, the unmarried mother of two children, was admitted to the Psychiatry Ward on June 4, 1946, and diagnosed as Schizophrenia, Paranoid type. The symptoms leading to hospitalization were ideas that she was being persecuted; auditory hallucinations; visions from God and a persistent wish to see a grandparent who was dead. Her mother thought that she had received a severe disappointment when the 
father of her two children led her to believe that he was planning to marry her and then refused to do so. She had also grieved considerably about the death of a girl who had been a close friend.

Niss Benton was being treated. with electroshock therapy and showing improvement when she was removed from the hospital by her mother June $24,1946$. Prognosis for recovery was poor.

PAREITAL HOME AND EARLY ADJUSTUENT:

Miss Benton was the second of three children reared in a poor environment. There was considerable friction between the parents and the economic standards were very low. The parents were well-known to various social agencies for a period of seventeen years, but in spite of economic difficulties the patient attended school through the ninth grade. Parental discipline was lax and the patient's companions were people of low morals. She had little knowledge of responsibility anc paid no attention to the hali-hearted and sporadic attempts her mother made to control her. Family ties were indifferent but the patient continued to live with her mother after her parents were divorced, and after the birth of her two illigitimate children.

\section{SEYUAL OR MARITAL ADJUSTMENT:}

Miss Benton had never married and although, she had "adventured quite a bit", according to her mother's statement, paternity of the two children was admitted by their father. Apparently the only deep heterosexual attachment she had ever experienced was to this man. The final breaking off of their relationship and the loss of hope of eventual marriage appeared to be the precipitating factor in her illness.

\section{INDUSTRIAL AND COMUNITY ACTIVITIES:}

The patient had worked at various jobs since leaving school. She had been employed as an elevator operator on two jobs, as a practical nurse in a lccal nursing home, and as a domestic servant on temporary jobs. She usually got along well with her employers but did not stay on her jobs for any length of time, usually quitting for no apparent reason and without giving notice. Her friends were from a low strata of society and they went from one beer garden to another in search of amusement. She had no interests outside of her beer drinking and "carousing", according to her mother's statements.

\section{POST-TREATMENT ADJUSTMENTS:}

Following discharge from Louisville General Hospital June 24, 1946 , Miss Benton stayed at home until August 15, 1946, when she was admitted to Central State Hospital. She was pulling out her hair because the "roots of her hair hurt," and was again hallucinating. She received a series of electroshock treatments and was paroled september 22, 1946, returned to the hospital on October 15, 1947 and again paroled December 26, 1947. She was seen by a medical student on May 31, 1947, in the routine follow-up, and it was recomended that she attend the Out-Patient Clinic. The patient had no 
insight and her feelings had not changed. She hac worked sporadically as a domestic servant and was not planning to get a regular job. The student felt that both her adjustment and prognosis were poor. It will be noted that five months after this contact the patient was again hospitalized for two months.

A follow-up visit was made to the home on April 15, 1948 by the writer. The patient and her mother reported that Miss Benton was getting along well, although she was worried about not having a job. She had worked at several temporary jobs and had applied for a Civil service job as elevator operator. She complained that her hair was falling out, later said that she pulled it out to "stop the pain". She showed no insight into her behavior nor her need for psychiatric out-patient treatment.

COMOENT:

This patient was considered as adjusting in the lower limits of Level 3. She had made a poor adjustment between hospitalization periods but had worked temporarily from time to time. She was getting along in her family position much as she had before her illness. In the protective environment of her mother's home she was able to remain out of the hospital for fairly long periods of time. On the other hand, it is possible that the environment was in part responsible for her relapses and that if a change in environment could have been made she might have held the improvement made by hospitalization and treatment for a longer period of time.

The cases of Mrs. Hale and Miss Benton illustrate similarities in the development of illness in two different kinds of environment. In Mrs. Hale's childhood she was sheltered and protected, received little training that would enable her to face adult responsibilities. There was a strong attachment to her mother but apparently there was a lack of adequate guidance in the development of social relationships. Miss Benton's early life, on the other hand, was that of a child growing up without strong attachments, lacking in parental discipline, with the possibility that parental rejection was the basis of the ineffectual and half-hearted attempts at control. Neither of 
these patients gained any insight into their illnesses, both returned to the same environments and the same conditions existing before the onset of psychotic symptoms. Two years after the study hospitalization both were manifesting symptoms similar to those preceding their hospitalization.

The paranoid type accounts for about 50 per cent of the cases of schizophrenia, according to a statement of Dr. Lowry. 1 He further states:

It (the paranoic type) tends to develop later in life than do the other forms. It may develop slowly over many years before some untoward event, such as a period of excitement related tc the ideas of persecution, an assault upon an innocent bystander, or some other bit of disordered or antisocial behavior makes hospitalization imperative. Such incubation periods may last for twenty or more years. During such a period, the patient may be regarded as efficient, but queer .....

Paranoid cases do not recover. Some do learn to cover up their delusions and hallucinations and so make a fair social adjustment. This is, perhaps, especially true if the hallucinations and delusions are focused on some one person or in some particular life area. Avoidance of the person or the area may then permit the paranoid individual to lead a fairly quiet, reasonably socialized existance. But, in general, remissions are less frequent and less complete than in the other types. 
CHAPTER III

CASE SUMMARIES OF TWO PATIENTS IN IEVEL 4 


\title{
CASE SUMMARIES OF TWO PATIENTS IN LEVEL 4
}

\author{
CASE 6 - Mr. Ward
}

THE PATIENT:

Mr. Ward, a single, negro male, twenty-seven years of age, was admitted to the Psychiatry Ward on February 21, 1946 and diagnosed as Schizophrenia, Paranoid type. Since the end of the war when he lost his job he had worried excessively and had excluded all other interests in favor of his religious activities. For six weeks preceding his admission to the hospital he had grown progressively worse. He was given to daydreaming, began wandering around at night, had feelings of persecution, delusions of grandeur, and auditory and visual hallucinations. When restrained by his father from going on the street without clothing, he became combative.

Mr. Ward was given electroshock therapy until March 15, 1946, when his family assumed responsibility for his care and removed him from the hospital against medical advice. He remained at home until March 28, 1946, at which time he had to be rehospitalized and was sent to Central state Hospital. He was paroled to his parents January 5, 1948.

PARENTAL HORE AND EARIY ADJUSTMENT:

Mr. Ward was the youngest of five siblings reared in a home of comfortable economic standards. There were no family conflicts and the family history was negative for mental illness or aberrations. His birth and early development were normal. He was always treated as the "baby of the family", protected and sheltered by parents and siblings alike, occupying a central but passive status in the family. He had a rather shy and retiring nature but got along well with other school children, having an average record in class work. He took a minor part in school activities and the athletic program. When $M r$. Ward was in his first year of high school, he dropped out of school because he felt that his parents could not afford to send him any longer. He was described as emotionally dependent on his mother and two sisters.

SEXUAL OR MARITAL ADJUSTMENT:

The parents stated that during adolescence $\mathrm{Mr}$. Ward had many dates with girls and attended dances and parties, leading a normally active social life. He attended church and Sunday School and was greatly interested in religious matters. The patient admitted with considerable guilt that he had participated in one homosexual experience when he was thirteen years of age. Under narcosis (release) therapy he revealed that there had been a series of such experiences from the age of nine until he began having heterosexual experiences at nineteen. He had no guilt feeling toward his 
heterosexual experiences. Mr. Ward had never been engaged nor particularly interested in any one girl, although he invited his current friend to the home from time to time.

INDUSTRIAL AND COMUNITY ADUUSTMENT:

Mr. Ward worked as a laborer until the war when he secured a job as mess attendant in a hospital. He was considered a good worker, having no evident conflicts with his environment or associates, but showing a lack of initiative. He had no close friends and was passive in community contacts, going out occasionally to dances or having dates for church affairs but seldom taking the lead.

\section{POST-TREATMENT ADJUSTMENTS:}

Approximately two weeks after Mr. Ward's relcase to his parents from Louisville General Hospital, he was admitted to Central State Hospital where he remained for twenty-one months. When a home visit was made by the writer two years after the study hospitalization, his parents did not want him interviewed. They felt that his adjustment was so precarious that contact with a member of the staff would be unwise. The parents stated that the patient had worked at a laundry for two weeks and had had several jobs of a temporary nature. They did not want him to attempt to hold a full-time regular job. Mr. Ward spent a greater part of his time walking around the neighborhood, going to church, and attending the Young People's Sunday School Class meetings. He talked about his friendship with girls but did not bring any of them to the home. The parents felt that Mr. Ward was improved but still far from well. They wanted to keep him at home as long as he was not violent because of his hatred for and feeling of dread for hospitals. They used the threat of the hospital as a means of controlling him "when he woulcin't behave."

COMENT:

This patient was considered to have attained an adjustment appropriate to Level 4, as it appeared that he was not contributing in any way and was being treated as a family invalid. It is coubtful if he will ever be able to make a better adjustment. His hospitalization periocis were marked by parental interference and any improvement in the patient resulted in too early removal from the hospital by his parents.

In this case there were two important factors which needed consideration: the patient's worry and guilt over homosexual experiences and the strong maternal ties. In many cases of peranoid schizophrenia, sexual conflict, conscious or unconscious, is present. Over-protection by this patient's 
mother and his emotional dependence on her added to the burden which the patient was unable to handle. Apparently the mother could not change her too protective attitude toward the patient and could not accept the fact that he actually might be better off away from her. Return to the same home situation was inaovisable but it wolld have required a great deal more time and work with the patient and his family to have made any other plan acceptable to them. As Dr. J.H. Taylor has stated: "..unquestionably the environment is the principal factor in the return (to the hospital) of many of the patients but the difficulty of changing the environment of the average patient can readily be recognized." I

$$
\text { CASE } 7 \text { - Ronald }
$$

\section{TIE PATIENT:}

Ronald, a thirteen year old, white male was admitted to the Psychiatry Ward from the Children's Center on February 16, 1946, and diagnosed as Schizophrenia, Paranoid type. He had been committed to Ormsby Village by the Juvenile Court in October, 1945, because he did not adjust to the type of supervision in his home. His adjustment at Ormsby Village was poor, irmediately before his admission to the hospital he had lost contact with his surroundings, believed he was Jesus and that people were trying to kill him. He was given electroshock therapy and released to the Children's Center as improved on liarch 9, 1946. The prognosis was guarded. When the plans for his placement did not work out he was returned to the ward on March 23, 1946 and again released to Children's Center on April 6, 1946.

PARFNTAL HOIE AND EARLY ENVIRONMENT:

Ronald was the youngest of three children, his brother was ten years older and his sister six years older. His parents were separated on two occasions before their final separation and divorce. His mother hao been an out-patient in the Psychiatric Clinic in 1942, with a diagnosis of Anxiety State; she wes over-solicitous about her own anc the children's health. The father drank excessively and gave the boy little supervision

\footnotetext{
IJ.F. Taylor, "Returns of Schizophrenics Following Shock Therapy",
} Diseases of the Nervous System, VI, 1945, p. 29. 
at the times the child was with him. The brother was apparently stable and was accepted for military service; the sister was thought not bright and rather "peculiar".

Ronald's birth and early development were nomal. He began teething at eight months, walked at ten months, talkec at fourteen months. He had spasms from the age of ten months to about two years, most of the time losing consciousness without convulsive movements. His mother found that if she laid him on the bed he regained consciousness in about half an hour. When he was eight years old, he fell on the pavement while playing and broke out his front teeth. Following this injury he began to have temper tantrums when he would throw things, kick, and bite.

He started to school at the age of six years and did well, attending regularly for about four years when he began to do poor work and was often truant. He was small, uncerweight and fearful but he was also headstrong and his mother usually gave in to him to avoid scenes. At a time when he was staying with his father, Ronald left home to avoid pressure about his truancy, and went to his maternal grandmother's home in Indiana. When he returned to Louisville with a note from his grandmother to his father, his father had him apprehended, committed to Children's Center and placed at Ormsby Village. Psychometric tests revealed that Ronald had borderline ability. At the Village he was shy and withdraw and although his behavior was superficially good his social worker felt that he never let anyone get close to him. He was placed in the ungraded class and was observed to be timid and unable to take up for himself.

POST-TREATMENT ADJUSTMENT:

When Ronald left the hospital the first tine it was planned that he woulc. go to the maternal grandmother's home, on a farm in Indiana. There was an aunt in the home who had several children, and she was thought to be a warm, understancing person. For a few days Ronald seemed very happy, then he began wanting to go to his mother and when he could not do this he became unmanageable. He was returned to the hospital and plans were made so that the mother could take him. This was not a satisfactory arrangement as she had remarried and had only one rented room; however, his mother agreed to take him and this plan was carried out. Ten days later she returned to Children's Center and complained that she could not keep the boy. She stated that he was abusive to her anc she was again sending him to his grandmother. She rejected any idee of a foster home placement and it was agreed that Ronald could go to his grandmother.

On April 3, 1948, Ronald was reamitted to the Psychiatry Ward with the same set of symptoms as before. His mother stated that she had done everything, she and her husband had moved to a farm near her parents to be near him and Ronald had gone back and forth between the two homes several times, a misfit in both places. His behavior had gown progressively worse and as he had not reentered school he had been uncerfoot all the time. After a short time on the ward, and a short series of electroshock treatments, Ronald was entirely lucid and had no tantrums. He expressed a desire to live with his sister who had married and had a small child. His sister had a four room apartment and was willing to take the boy into her home. He was discharged in her care on April 10, 1948 and a week or two later came to the ward to say that he was getting along well there. 
COMAENT:

Ronald was classified in Level 4. He was not attending school and the length of time since his last hospitalization was too short to cietermine whether he would continue to adjust even at this level. Because of the serious rejection and emotional deprivation he has undergone, it is questionable if good adjustment will be possible anywhere. The complete lack of security he has felt has been such a continuous experience for him it is likely that he will continue to react with occasional outbreaks. During hospitalization with electroshock therapy, recovery from the episodes was rapid but, unfortunately, adequate facilities for extended treatment for children are lacking and it was necessary to place him where he again had the same conflicts. In his sisters home where he felt wanted and where there are no children his own age to offer competition, he may be able to stay out of the hospital for long periods.

The frequency of schizophrenia in children is thought to be about one per cent of schizophrenia in all ages. The studies and reports of incidence of schizophrenia in children vary in regard to similarity of childhood types and adult types. Several authorities agree that there are two types in childhood: The first, a periodically agitated type, characterized by acute onset with remission and exacerbation; the second, characterized by a slow and insidious onset. A third form is mentioned which implies that the schizophrenic process is superimposed and grafted upon an underlying feeble-mindedness. Nost authorities agree that the paranoid type is rarely found in children. Some authorities believe that the home atmosphere causes the onset of symptoms and most of the 
emotional outbursts. There have been ciscussions of the relationship between childhood schizophrenia and childhood hysteria, and it is believed by some that there are many intermixtures. I

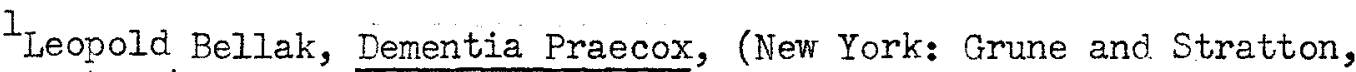
1948). pp. 422-430. 
CHAPIER IV

CASE SUMARIES OF THREE PATIENTS IN LFVELS 6 AND 7 
CHAPTER IV

CASE SUMMARIES OF THREE PATIENTS IN LEVELS 6 AND 7

CASE 8 - Miss Maxwell

THE PATIENT:

Miss Maxwell, a single, white female, thirty-two years of age, was admitted to the Psychiatry Ward July 3, 1946, and diagnosed as Schizophrenia, Paranoid type. She was brought to the hospital by a brother-in-law after she had threatened to kill two of her sisters with whom she had been living. History secured from her sisters revealed that the patient had suffered a nervous breakdown in 1932 when a student to whom she was engaged broke their engagement. At that time she had had headaches and fainting spells for about two months and after she improved she became reticent and reserved. She continued to have occasional dates but never appeared to care deeply for anyone else. About six years before the study hospitalization she became suspicious and more seclusive. Two and a half years before hospitalization she complained to a sister that the man with whom she had gone out had made improper sexual advances to her. She had never gone out with men since that time. In September, 1945, she became more seclusive and would lock herself in her room or the bathroom, began to think people were spying on her and that her family was trying to poison her. It was not until she began threatening that the family felt unable to cope with her themselves.

Miss Maxwell was treated with electroshock therapy but when she showed no improvement it was felt by the hospital staff that she would need a long period of hospitalization. She was transferred to Central State Hospital on July 18, 1946, with a prognosis of very poor.

PARENTAL HOME ANT EARLY ADJUSTMENT:

Miss Maxwell was the fourth of eight children. There were two sisters and one brother older, and three brothers and one sister younger than she. There was no familial history of mental or nervous manifestations. As a child Miss Maxwell was subject to severe headaches and vomiting spells which occurred about once a month and lasted for a day or two. She was deeply attached to her mother but had little regard for her father, resenting and blaming him for the low income and his lack of ambition. She alwars dressed immaculately and her personal habits were above reproach. She wanted nicer clothing and accessories than her father's income afforded and quit school in the third year of high school to go to work. Her school record was good, she had no scholastic, disciplinary, nor social difficulties. She was popular vith both sexes and had a pleasing personality. She was deeply grieved by her mother's death in 1942 and although other members of the family were sympathetic and understanding she tended to withdraw from them. 
SEXUAL OR MAEITAL ADJUSTMENT:

Miss Maxweli's unfortunate love affair at the age of ninteen was the only ceep attachment she had for any man. It was at that time that she again suffered from headaches and other physical complaints as she had in early chilchood. No sexual history could be secured from the atient and her family thought she had not had any sexual experience.

IMDUSTRIAL AND COMUNITY ADJUSTMENTS:

When Miss Maxwell first started to work she held her jobs for long periods and was a very efficient office worker. At the time she became suspicious and seclusive (about six years before hospitalization), her family noticed that she began to change jobs frequently, although she continued to be efficient. Her family believed, at first, that these changes were made in an effort to better herself, later they found that she would become suspicious of her employers. She often thought that her employers were trying to poison her.

As stated previously, Miss Mazwell had been popular as a young girl but for several years prior to the acute stage of her iliness she had tended to withcraw from any social life. She took no part in any community activities and preferred reacing to any other recreation.

POST-TREATNENT ATUUSTTENT:

Two years after Miss Haxwell was transferred to the State Fospital she was visited there by the writer. She was well dressed, her hair was arranged attractively and her face nade up as if she were going out. Her delusions had crystallized and she spoke of her family as her foster family. She thought they were keeping her in the hospital to keep her from inheriting the vast estate left to her by her "real" father. She had only recently been given ground privileges and had no work detail although she helped with routine duties on the ward.

COMTENT:

This patient was classified in Level 6, a less productive hospital invalid. She is one of those patients who do not respond well to electroshock therapy. It has been noted that where the onset of schizophrenia is gradual anc insidious over a period of years that hope of recovery is slight. In a study by Drs. Kalinowsky and Worthing ${ }^{I}$ they pointed out that the paranoid schizophrenic with delusions and hallucinations have the best cutcome.

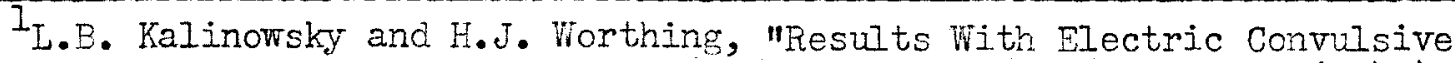
Therapy in 200 Cases of Schizophrenia", Psychiatric Quarterly, XVII, (1943) p. 144 . 
In the two hundred cases they studied there were 67.4 per cent remissions for cases of less than six months duration; 43.1 per cent remissions for cases with duration between six months and two years; and only 9.2 per cent where the duration had been more than two years.

It is difficult to fix reliably the onset with this patient but the history indicates that it developed progressively over a period of years. There hac been several episodes when the patient may or may not have been psychotic, but for at least two and one half years there had been definite personality changes with oddities in behavior. That there was an underlying sexual conflict is borne out by the fact that the first marked peculiarities occurred after the unfortunate love affair and this affair had preyed on her mind for thirteen years, and also by her accusations regarding abnormal sexual advances made to her.

\section{CASE 9 - Carl}

\section{THE PATIENT:}

Carl, a sixteen year olc, single negro male, was acmitted to the Psychiatry Ward on March 19, 1946, and diagnosed as Schizophrenia, Catatonic type. He had a history of several previous attacks of illness and had been studied in a medical college in a neighboring state. He had a previous admission to Louisville General Hospital in 1942 but remained only one day before his perents removed him against medical advice. Prior to the study admission he began engaging in fights, housebreaking, painting his nails, and roaming the streets. At home he was negativistic and wanted to go around without clothing. His family thought his first peculiar behavior started after the death of a schoolmate in 1940. He had no professional attention at that time but his mother gave him a great ceal of attention. He was deeply affected by his mother's death in 1944, but did not require hospitalization. At the time of the study admission, his father was seriously ill in a local hospital. In intervals between these episodes, Carl made a fair to good adjustment, continuing in school with good grades. He received electroshock therapy until his transfer to the Central State Hospital on April 11, 1946, with a poor prognosis. He was paroled from Central State Hospital on two occasions, his last readmission being March 6, 1948. 
PARENTAL HONE AND EARLY ENVIRONMENT:

Carl was the oldest of four siblings, having two brothers and a sister. There was no unusual heredity in the family, which was above the average in economic and cultural standards. His father was a professional man with a well-established practice, the parents were congenial and affectionate with the children. Carl's birth and early development were normal, according to his mother's statement in 1942 when he was on the ward for one day. She statec that he was enuretic but it was because he had "weak kicneys". Carl's mother was conscientious about caring for the children and Carl was unusually close to her, particularly after the death of his schoolmate. At that time he had night terrors and would awaken in the night, very excited and tell his mother that he had seen the body of his friend. He finally recovered from these night terrors and was apparently normal until June, 1942, when he again became wakeful and nervous at night. These fears gradually subsided during a period of treatment at the Medical College ano did not start again until August 1946 when he became solemn, would not speak unless spoken tc, and began the fighting anc housebreaking. History of his behavior during his mother's illness and death in 1944 was not obtainable as his father was ill at the time of his admission and his step-mother did not know anything about him at that time. His step-mother was rather indifferent to the boy when he was not ill but was afraid of him then.

SEXUAL OR MARITAL ADUUSTMENT:

Very little information was obtainable concerning Carl's sexual development or knowledge. He gave a story about having had a venew infection during the summer of 1945 and he boasted of frequent relations with girls but his brother thought all of these stories were falsifications. There were no known nor admitted homosexul exoeriences. The patient stated that he always kept his nails painted and would fight anyone who laughed at nim.

INDUSTRIAL AND CONONITY ADJUSTMENTS:

Carl was superior in his school work and had attained the ninth grade. He was described as a hard-working conscientious boy who carried one or two paper routes after school. Prior to his first attack in 1940, he had tended to have a few very close friends but was not a good mixer in a crowd. Afterward, he did not seem to have close friends and kept himself busy with his school work and the paper routes. Between episodes he attended school and had odd jobs, apparently doing well. When brought to the hospital, he had been out of school for three weeks.

POST-TREATIENT ALJUSTMENTS:

Carl continued to receive electroshock therapy at Central state Hospital anc recovered sufficiently to be paroled to his father. However, he hac to be returned, later was again paroled and again readmitted. On the last readmission he hac been at home only four months. At the time this study was made he had received another series of electroshock treatments but showed no improvement. He was cooperative but untidy, helped with routine ward cuties but was not assigned to a work detail. 
COMENT:

At the time of this study Carl's adjustment was considered to be in Level 6 as he appeared a less productive hospital invalid. In the two-year interval between the study hospitalization and the time the study was made he had shown remissions and exacerbations of symptoms. It is interesting to note that the informants connected the first symptoms of abnormal behavior with the death of a friend and that hospitalization occurred approximately two vears later. Two years after the death of his mother, during which time his father had marrjed a much younger woman, he again had to be hospitalized. The increasing frequency of the episodes after his mother's death might be due in part to his feelings around his father's early second marriage and his step-mother's lack of understanding. The rate for spontaneous recovery of catatonic schizophrenics is higher than that of the other types of schizophrenia. This case, however, is complicated by the age of the patient when his first symptoms appeared. His first electroshock treatrnent (reported by the Medical College who treated him in 1942) took place when he was only twelve vears old, anc the prognosis for childhood schizophrenia is very poor.

\section{CASE $10-M r$. HaskeII}

\section{THE PITIENT:}

Mir. Haskell, a white, divorced, thirty year old male, was admitted to the Psychiatry Ward in a confused and agitated state, on May 20, 1946. The admitting diagnosis of Psychopathic Personality with Psychotic Episodes was later changed to Schizophrenia, Catatonic type. He had quit coing the simple jobs around the house thet he was accustomed to doing, had become very quiet and thoughtful, and would sit and gaze at his mother or sister all day. He had refused to eat for several cays, appearing afraid of the food. Fe was given a series of electroshock treatments at Louisville General Hospital and when he showed no improvement was transferred to Central State Hospital on JuIy 5, 1946. He had previously been known to the Psychiatric Out-Patient Clinic in 1945, and much of his history was secured from that record. 
PARENTAL HONE AND EARLY ENVIRONMENT:

The patient was the fifth in a family of six children. They were people in a marginal or sub-marginal group. The patient's birth and early. environment were normal and he was described as a well-adjusted child. Throughout his life there was a strong attachment to his mother and in later life it fell to him to support her and care for her. As a child Mr. Haskell had no close friendships but played with a group of both boys and girls. When he was eleven he met the girl who later became his wife. He was absent from school quite often after he met the little girl and his scholastic standing started to fall. He quit school at fourteen years of age to go to work and married at the age of sixteen.

SEXUAL OR MARITAL ADUUSTMENT:

During the interviews in the Out-Patient Clinic Mr. Faskell had shown an interest in discussing homasexuality but denied that it had ever been a threat to him. He admitted some experience and contacts with others who submitted to homosexual relations, he also admitted that he had sometimes hac the feeling that other people thought that he might be homosexual.

Mr. Haskell, a Protestant, married a furteen year old Catholic girl, when he was sixteen. They were quite happy for a year or so, seeming compatible sexually and emotionally. However, his wife apparently had a much stronger sexual crive and began going out with other men. Wr. Haskell retaliated by doing the same and their quarrels led to divorce after they had been merried about five years. Shortly after the divorce Mrs. Haskell married a man who worked at night and returned to spend her wedding night with Mr. Haskell. They had had no children during their marriage, but the patient's mother, in giving the history, stated that the ex-wife's seven year old son bore a strong resemblance to $\mathrm{Mr}$. Haskell.

Mr. Haskell admitted that he was still in love with his wife and that she had made several attempts at reconciliation. He could not forget her extramarital experiences and feared that remarriage would lead to the same trouble. She continued to seek him out and plead with him until he was injured in an accicient on a job where he was working with heavy machinery. In the meantime Mr. Haskell had felt guilty about his own behavior in going out with prostitutes and other women of low morals. He had once been threatened with a breach of promise suit and had once contracted a venereal disease.

INDUSTRIAI AND COMITNITY ADJUSTMENTS:

The patient went to work as a laborer soon after he quit school in the fifth grade. He made a good acjustment on his jobs even after his injury, although at that time he had told his foreman that he thought "he was losing his mind". He made a fairly gooc living in spite of the fact that after his divorce he becarie addicted to the use of morphine. Ie quit the morphine habit abruptly after a friend had died from an overcose and his mother had commanded him to quit. Later he drank moderately for about a year but quit that habit abruptly, also, after some unpleasant experiences. 
Mr. Haskell was $r \in j e c t e c$ for military service because of the residuals of the accident to his right arm. He was able to work, however, anc did work rather regularly but with frequent job changes, until about a year prior to his hospitalization. The reason for quitting work was that one night he did not return home but wandered around town all night. When he came home at dawn his mother called in a physician who said his condition was due to nervousness. He did not attempt to hold a job after that but did cultivate a small garden, papered the house, washed the windows and helped generally around the house, until a few weeks before his admission to the hospital.

POST-TREATMENT ADJUSTINENTS:

Three months after transfer from Louisville General Hospital Mr. Haskell escaped from Central State Hospital. He was apprehended the same day and returned, escaping again two months later. He went to his mother's home and she returned him to the hospital within three days. Two months after his return his mother removed him on parole from the hospital. He remained at home until December 1947, a period of ten months. In the early part of his stay at home he seemed satisfied and went out occasionally, but after a few months he again became negativistic, would not leave his room, refused to eat and wouldn't let his mother keep him clean. He would act threateningly toward her if she persisted in her efforts to control him.

In the State Hospital he has no duties, appears to have deteriorated and spends his time sitting and gazing into space. Electroshock therapy was discontinued as there was no improvement.

COMMENT:

Mr. Haskell is classified as adjusting in Level 7, the deteriorated hospital invalid. This case illustrates the degenerative process sometimes observed in the catatonic schizophrenics. Perjods of negativism may alternate with periods of excitement and the patient can become dangerous with little or no warning.

It is interesting to compare the post-treatment adjustment of this patient with that of Mrs. Echols ${ }^{I}$ who returned from the hospital to a happy home situation. Mr. Haskell had never been able to resolve his ambivalence in loving and wanting his wife back and his lack of confidence in her. His guilt feelings concerning his own sexul activities had also been a heavy burden. 
His dependence on his mother and their close attachment was probably a factor in his emotional conflicts. 
CHAPTER V

DISCUSSION AND CONCLUSION 
The purpose of this study was to inquire into the social adjustment of schizophrenic patients who received electroshock treatment at Louisville General Hospital in 1946. Twenty-one cases were studied and ten considered to be representative of the total group were presented. In order to determine the adjustment these patients made and the level of usefulness to which they were restored it was necessary to study as many of the known facts as possible concerning their pre-illness adjustments. In the opinion of the writer, certain prognostic factors would carry some weight in the evaluation of the level of adjustment attained by each patient. The list of such factors suggested by Drs. Kalinowsky and Hoch $^{I}$ offered a ready frame of reference for follow-up study. They state:

In evaluating the prognosis in schizophrenia, it is generally agreed that the following factors require consideration:

1) Heredity, age, sex

2) Duration of illness, previous attacks

3) Type of schizophrenia, typical or atypical clinical picture

4) Type of onset, presence or absence of precipitating causes

5) Constitutional and personality make-up; social, sexual, and personality adjustments before onset of illness

While it is recognized that no one factor was intended for use incependently of the others, for study purposes they will be discussed separately.

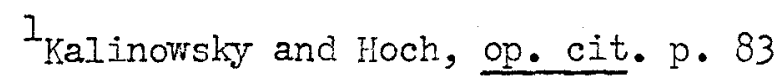


THE PATIFNTS:

The importance of the heredity factor is debatable as no definite conclusions have been drawn as yet from research. Dr. Bellak states:

It is almost universally accepted that the familial incidence of dementia praecox is significantly greater than the incidence in the general population. The interpretation of this fact differs among the different investigators; they attribute it to completely social transmission, to completely hereditary transmission, or to a combination of both.

In eight of the ten cases presented in this study no familial history of mental illness was elicited. Mrs. Cain, ${ }^{2}$ diagnosed as a mixed type, had an aunt who had been institutionalized for a mental illness, and another aunt who was described by relatives as "being like Mrs. Cain". A diagnosis of Anxiety State had been made in Out-Patient Psychiatric Clinic on the mother of Ronald, ${ }^{3}$ the thirteen year old boy who was admitted with a diagnosis of paranoid schizophrenia. His father was described as an excessive drinker and an unstable person, by reliable informants, and his sister was thought "not bright" and "peculiar". These two patients were making wicely different adjustments. Mrs. Cain was thought to be doing as well as before her illness, and attempts were still being made to find a suitable home placement for Ronald among relatives, none of the previous attempts having been successful. In the twenty-one cases studied, information obtained from relatives indicated that in the family history of sixteen of the patients, there was no mental illness, while five of the patients had one or more relatives who had been mentally ill.

The concensus of opinion among investigators who have studied the effect of electroshock therapy on schizophrenics is that when the onset occurs before

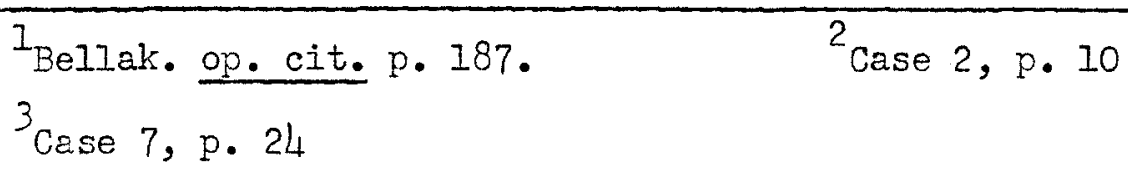


the age of fifteen or beyond the age of forty the prognosis is unfavorable. The findings of this study, which is of course too small to offer significant material relative to this, partially bear out this prognostic factor. Among the ten cases presented, five patients in the three higher levels of adjustment ranged in age from twenty-five to trirty-six. The five in the lower levels included two adolescent boys, Ronald, age thirteen, and Carl, I aged sixteen; the three others were between the ages of twenty-seven and thirty-two.

In the twenty-one study cases the range in age was somewhat wider, those in the higher levels varying from nineteen to forty-three; those in the lower levels varying from thirteen to forty-one.

Some studies ${ }^{2}$ indicate that the spontaneous remission rate is higher in females than in males. others ${ }^{3}$ contend that the prognosis is slightly better with male schizophrenics than with the female schizophrenics. The importance of the patient's sex in response to electroshock therapy is still a matter of controversy.

In the twenty-one cases available for this study there were fifteen females and seven males. The ten cases presented included six females and four nales.

Duration of illness and history of previous attacks are considered anong the most important factors in prognosis. Authorities are in agreement that the best results with electroshock are obtained with patients who have been ill no longer than one year. The usefulness of this factor, however, is recuced by the fact that it is not easy to fix reliably the curation of the psychosis in many peitients. Insidious development is not uncommon, and a schizoid per-psychotic personality sometimes merges imperceptibly into a psychosis.

$$
\begin{array}{ll}
{ }^{1} \text { Case 9, p. } 31 & \text { 2Kalinowsky and Hock, op. cit. p. 83. } \\
3_{\text {Bellak, op. cit. p. 395. }} &
\end{array}
$$


for this reason the history of the duration of the psychosis obtained even from close relatives may be chronologically inaccurate.

The findings in this study were in agreement with the statement that the best results are obtained with patients who have been ill less than a year. Mrs. Hoover, ${ }^{1}$ whose post-treatment adjustment was considered better than her pre-iliness acjustment (Level 1), hed physical complaints and a period of hospitelization for bromide intoyication several years prior to the development of psychotic symptoms. Miss Maxwell ${ }^{2}$ a less oroductive hospital invalid at the time of the study, had a history of a nervous break-down fourteen years earlier, with a personality change dating from that time. Amons the remaining ten cases and in the entire study group, those whose acjustment justified classification in the higher levels had been ill the shortest period of time, and those whose adjustment was poorest had been described as having pre-schizoid personalities.

Two of the ten presented cases had a history of previous hospitalization. As previously mentioned, Mrs. Hoover's hospitalization was for bromice intoxication. Carl was treated in a neighboring state four years prior to the study hospitalization. Nrs. Cain's history incicated that she had suffered two nervous break-downs, a professional description of which was lacking as she had not received mecical treatment. Among the other patients several. histories contained references to minor oddities in behavior. Among the twenty-one cases studied, eight gave histories of previous hospitalizations for psychotic behavior.

The sub-type of schizophrenia is considered an important factor in prognosis. Most of the authorities on electroshock agree that the catatonic,

$$
{ }^{1} \text { Case 1, p. } 8
$$


in the excited stage, responds well and the stuporous catatonic, less well. The paranoid schizophrenic has a good prognosis only if treated in the first year after the psychotic manifestations appear. This form of schizophrenia has shown little tendency to spontaneous recovery, with a high relapse rate in follow-up studies. The hebephrenic and simple types are much less amenable to treatment. ${ }^{I}$

The three catatonic patients, Mrs. Echols, ${ }^{2} \mathrm{Mr}$. Haskell, ${ }^{3}$ and Carl, illustrate different degrees of response to electroshock therapy. Mrs. Echols and Mr. Haskell were admitted to the hospital because of withdrawal reactions, Carl, in an excited stage. When the study was made, Mrs. Echols was adjusting as well as before her illness (Level 2), however, there were several favorable factors in her case, a loving and understanding husband, children who needed her, and a precipitating cause. Mr. Haskell's response to electroshock was poor and although he had been permitted home visits during the two-year period, at the time of the study he was a deteriorated hospital invalid (Level 7). Carl became more comfortable after a series of treatments but at the tine of the study had had three readmissions to Central state IIospital and was a less productive hospital invalid. Mrs. Cain had both catatonic and paranoid symptoms and was diagnosed as a mixed type. She responded well to electroshock therapy and after discharge from the hospital made some environmental changes which enabled her to make an adjustment which was considered as good as her pre-illness adjustment.

The five paranoid schizophrenics in the presented cases showed various responses to electroshock treatment. Mrs. Hale ${ }^{4}$ and Miss Benton ${ }^{5}$ were consicered less productive patients remaining out of the hospital in fairly
I Kalinowsky and Hoch, op. cit. p. 86.
${ }^{2}$ Case 3, p. 13.
${ }^{3}$ Case $10, p .33$.
${ }^{4}$ Case $4, p \cdot 16$.
${ }^{5}$ Case 5, p. 17 
protected home environments. Mr. Ward $d^{l}$ and Ronald were also out of the hospital in protected environments but both had been rehospitalized during the two year interval between the study hospitalization and this study. Miss Maxwell, a less productive hospital invalid had remained in Central State Hospital continuously with no improvement from electroshock treatment. The hebephrenic patient whose case was presented, (Mrs. Hoover), on the other hand had show amazing recovery with considerable insight. No doubt favorable factors, such as her out-going personality, comparatively short duration of iliness and the presence of precipitating factors outweighed the unfavorable factors.

The entire group of twenty-one cases were classified in the levels of adjustment according to sub-type of schizophrenia as follows:

\begin{tabular}{|c|c|c|c|c|c|c|c|c|}
\hline LEVEL & 1 & 2 & 3 & 4 & 5 & 6 & 7 & Total \\
\hline Paranoid & I & 2 & 4 & 4 & - & 1 & 1 & 13 \\
\hline Hebephrenic & 1 & - & 1 & - & - & - & - & 2 \\
\hline Catatonic & - & 1 & $\overline{1}$ & 1 & - & - & 2 & 5 \\
\hline Simple & - & - & - & - & - & - & - & - \\
\hline Mixed & 1 & - & - & - & - & - & - & $I$ \\
\hline & 3 & 3 & 6 & 5 & - & $I$ & 3 & 21 \\
\hline
\end{tabular}

The type of onset and the presence or absence of precipitating events is thought to have diagnostic and prognostic value. In general, the outlook is more favorable in cases with some definite precipitating event and with an acute onset of psychotic symptoms. Acute onset and precipitating events were observed in the case of Mrs. Echols whose symptoms appeared five weeks before admission. Gradual onset and no precipitating events were noted in the case of Ronald whose difficulties started early in life. The precipitating events fall into general categories and occurred in the entire group with the 
following frequencies:

Sex and marital difficulties..................

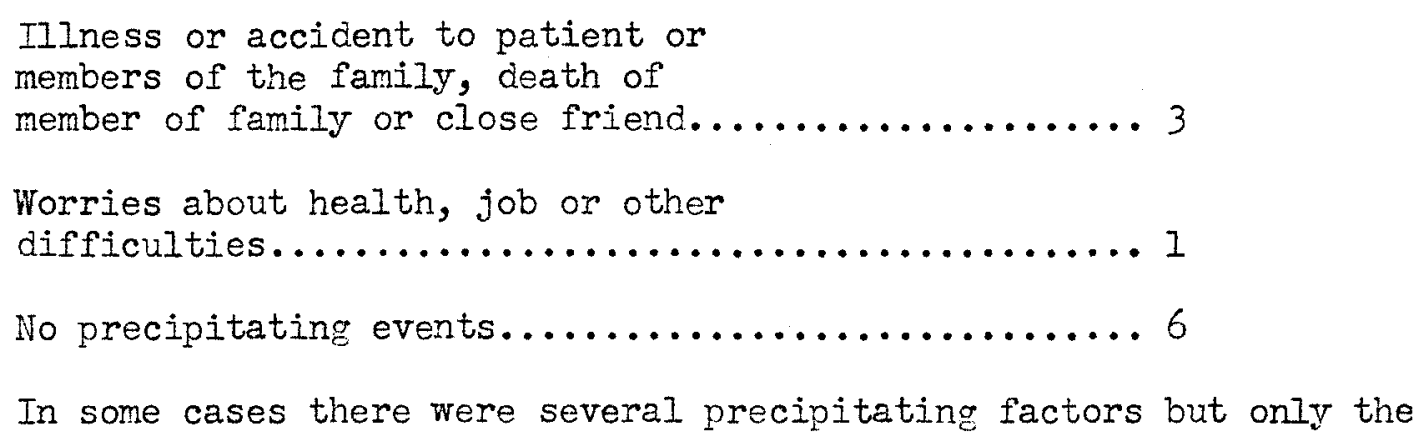
most dominant was counted in each case.

The fifth prognostic factor, constitutional and personality make-up; social, sexual and personality adjustments, are dealt with under subsequent headings.

PARENTAL HONE AND EARLY ENVIRONUENTS:

Parental and siblings relationships in early life are important in determining an individual's ability to form relationships with others throughout the remainder of Iife. Homes broken by the death of one or both parents, or disorganized by the emotional conflicts caused by differences in personalities may lead to insecurity and instability of family members. Only one of the demonstrated cases, that of Ronald, the youngest of the group, came from a home broken by divorce. He had never experienced a normal home life and was shifted from one parent to the other and to the grandparents, with emotional upheaval attending each move. Miss Benton's parents were divorced after she was grown, but there were evidences of family conflict throughout her life. Carl, the sixteen year old boy, lost his mother by death when he was fourteen; however, his first hospitalization for psychotic behavior preceded her death by two years.

There were evidences of lack of balance in parental care and affection in several of the cases. Strong emotional attachments to other members of 
the family were noted frequently in the patients' histories, as was an over-protective attitude by the mother. Miss Maxwell, the paranoid schizophrenic, whose personality change dated back fourteen years, had a marked aversion for her father and a close attachment to her mother. Mrs. Echols had an unusually close relationship with her mother and her own description of the onset of her illness was that "her mind snapped when her mother died". Mrs. Hale was "very close" to her mother and made no friends outside the family.

The individual's position in the family constellation has significance in the inter-family relationships. It is interesting to note that none of the patients in the entire group was an only child. Four of the patients occupied the place of the oldest child in the family, while seven were the youngest.

Psychometric tests were not given routinely at Louisville General Hospital in 1946 and mental ages of the patients were not available. It was noted, however, that only two of the patients stopped school before entering the fifth grade. Ronald, the thirteen year old boy, had difficulty in learning and it is probable that this inability was largely due to emotional factors. Mr. Haskell quit school at the age of fourteen to go to work and married at the age of sixteen. Two of the patients had finished one year of college and four others had graduated from high school. SEXUAL OR WARITAI ADJUSTIETT:

Sexual or marital difficulties are present in many cases of schizophrenia. Ir. Bellak states:

In discussing marital status in relation to dementia praecox, ralaberg $^{l}$ finds that the married had the minimum rate, the single had the highest rate, with the divorced lamost as high as the single. There are several factors at work here: The personality traits which are found in the pre-

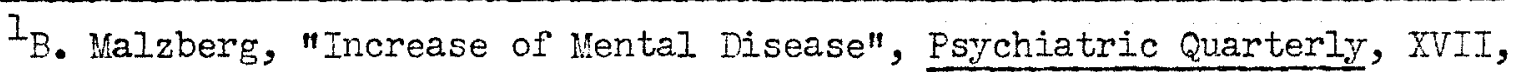
1943, pp. 488-507
} 
psychotic personality are such that the marriage rate would be lower for this group than for the general population; also these same traits, once they assert themselves would make it difficult for a marriage to survive. In addition to these factors, Malzberg feels that marriage itself may have a beneficial effect upon some individuals who might otherwise become psychotic. 1

The beneficial effect of a good marital adjustment was demonstrated in the case of Mrs. Echols who was adjusting as well two years after treatment as she was prior to her illness. There was marital conflict from the start in the case of Mr. Haskell, who married a fourteen year old girl when he was sixteen.

Some of the sexual conflicts may arise from failure of the individual to identify himself or herself with the proper sex. One report ${ }^{2}$ states that in a study made using the Terman-liles interest attitude analysis test for masculinity and femininity in psychotic patients, forty schizophrenic males and fifty-nine schizophrenic females were tested. Among the males, sixty-six per cent deviated to the feminine side and forty-seven per cent of the females deviated to the masculine side. As previously brought out ${ }^{3}$ in fifteen of the twenty-one cases where precipitating factors were present, sexual or marital difficulties were noted in eleven cases. INDUSTRIAI AND COMNUITY ADJUSTIFNTS:

The pre-illness personality is reflected in the adjustment an individual makes in his occupation and in the community. It has been noted that many schizophrenics have made satisfactory industrial adjustments over long periods of time when the illness was not severe and the habitual routine of their job not disturbed. The employment history of others may be characterized by frequent job changes and unfriendly relations with employers or co-workers.

\footnotetext{
I Bellak. op. cit. p. 15. ${ }^{2}$ Bellak, op. cit. p. 107

3 Supra. p. 39
} 
The pre-illness industrial or occupational adjustment of the cases presented was not considered significant inasmuch as two of the male patients, Ronald and Carl, were adolescents, and four of the females, Mrs. Hoover, Mrs. Cain, Mrs. Echols, and Mrs. Hale had no employment history. The others had frequent job changes, seldom working over a year in the same job. As to community adjustment, few of the patients took part in community activities, and those who did limited their activities to church affairs. only a few patients participitated in any sports in childhood or adulthood. Not one of the patients gave a history of a satisfying hobby nor did any one of them have club affiliations. With the exception of Mrs. Hoover and Mrs. Echols, who were described as friendly and out-going, the patients appeared to have introverted personalities. Miss Maxwell, up to the time of her broken engagement had been popular and friendly. Mrs. Cain, who had suffered two nervous break-cowns prior to hospitalization, was referred to repeatedly as "shy" and having "an inferiority complex". Mrs. Hale was described over and over as having been a quiet, withdrawn child. POST-TREATMENT ADJUSTEENTS:

The time elapsing between the study hospitalization and the study varied with the individual cases as not all of the patients were admitted to the hospital at the same time, but the average length of time was two years. At the time the study was made, of the twenty-one patients studied, two were believed to be making a better adjustment to their living conditions than they were before receiving shock treatment, these were, of course, classified in Level 1. Four of the patients were doing at least as well as before their illnesses and were classified in Level 2. Six were at home and getting along in their family position and employment with slight protection, therefore, 
they were classified in Level 3. Five of the patients were at home but needed a great deal of protection, some receiving a degree of care equivalent to hospitalization, these were the home invalids in Level 4. None of the patients was working at unsupervised hospital jobs, so none of the twenty-one could be classified in Level 5. There was one patient who performed routine ward work in the hospital and was a less productive hospital invalid, classified in Level 6. Three of the patients were unable to do any work in the hospital and were vegetative hospital invalids, they were, of course, classified in Level, 7 .

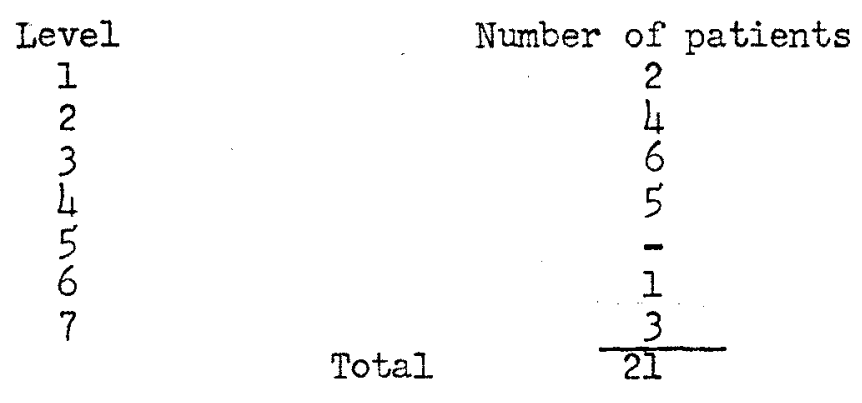

It must be emphasized that adjustment is not static and that at any period within the two years a different distribution would undoubtedly have been found. It should also be stated that some of the patients who were at home could not have remained out of the hospital without the constant care and supervision of a member of the family. On the other hand, some of the hospitalized cases might have been released if home conditions had been more favorable for adjustment.

All authorities agree that the inter-personal relationships are of extreme importance and that often a patient's readmission is due to his return to the same environment after successful hospital treatment. Environmental changes were made by two patients who were adjusting in the higher levels. Mrs. Hoover removed a source of conflict when she had her daughter's family move out of her home. Mrs. Cain divorced her husband, got a job and had her 
mother live with her to care for her children. Mr. Haskell and Carl were paroled from the hospital and had to return when they could not maintain the improvement they had made in the hospital.

The difficulty of making changes in the environment is recognized. The use of psychiatric social workers in some institutions has been an invaluable service in enabling patients to make better adjustments and remain out of the hospital for longer periods. 1 CONCLUSIONS:

1. In an inquiry into the post-treatment adjustment of patients treated by electroshock therapy the Table of Thomas A.C. Rennie, with some revisions is a valuable aid in evaluation of the patient's adjustment. 2. The prognostic factors listed by Kalinowsky and Hoch may be used as a ready frame of reference for stucy of the psychiatric history of schizophrenic patients.

3. All prognostic factors in the above-mentioned list must be considered together to get a clear picture of the probability of social recovery.

4. At the time of the study two were believed to be making an adjustment superior to that prior to shock treatment, four were doing as well as before, six were getting along out of the hospital with slight protection, five were home invalids requiring a good deal of care, one was a less productive hospital invalid and three were vegetative hospital invalids. 5. Findings of the study suggest that adjustment is not static and that within each level there are appreciable differences between patients at the upper and lower limits of a given level.

IMinna Field, Psychiatric Social Work with Insulin Treated Patients, (New York: State Hospitals Press), 1945 
6. Since the emphasis is put on the environment to which the patient is discharged and the effect that this environment has upon his ability to attain and maintain the best possible level of adjustment, an understanding of the environment becomes an important part of prognostic study. This, in turn, would seem to point to the importance of and adequate social service program in conjunction with psychiatric care for schizophrenic patients treated with electroshock therapy.

7. Inasmuch as some schizophrenics relapse after remissions which last as long as ten years or more a more valid and conclusive study into the post-treatment adjustment of these patients would have to be made at a later date. 
A P P EN D I X 
SCHEDULE: USED IN STUDY

Name
Address
Date of Birth
Admitted
Voluntary
Committed

Previous shock treatment

Disposition

SSE

Unusual Heredity

Place in family constellation

General Health

Onset of symptoms

Socio-economic problems

Financial

Vocational

Family Relations
Sex

Chart \#

Marital status

Education

Date of Admission

Date of Discharge

Type of Discharge

Occupation

\author{
Pre-illness personality \\ Friendly, out-going \\ Withdraw, seclusive
}

Family attitudes toward patient

$\begin{array}{llll}\text { Acceptance } & \text { Withdrawal } & \text { Hostile } & \text { Overprotection } \\ \text { Rejection } & \text { Worried } & \text { Friendly } & \text { Helpfulness } \\ \text { Resentment } & \text { Patience } & \text { Misunderstanding } & \text { Fear } \\ \text { Shame } & \text { Impatience } & \text { \& Ignorance } & \text { Dislike } \\ \text { Unashamed } & \text { Interest } & \text { Sympathy } & \end{array}$

Patient's attitude toward family

$\begin{array}{lll}\text { Acceptance } & \text { Withdrawal } & \text { Friendly } \\ \text { Rejection } & \text { Worried } & \text { Unfriendly } \\ \text { Resentment } & \text { Hostile } & \text { Fearful }\end{array}$

Interests of patient

Vocational

Hobbies and recreation

Friendships and associations

Immediate precipitating events

Sex and marital difficulties

IIIness, accident to patient or family

Death in family

Worries about health, job or other difficulties

No precipitating events 
Prognosis at time of discharge

Follow-up

Post-treatment contacts

With hospital staff

With Social Agencies

Milieu to which returned

Employment

Social adjustment

Vocational

Hobbies and recreation

Friendships and associations

Personality

Friendly, outgoing

Seclusive, withdrawn

Subsequent treatment and hospitalization

Level of functioning to which restored 
B I B I I G R A P Y 
BOOKS

Bellak, Leopold. Dementia Praecox. New York: Grune and Stratton, 1948.

English, O. Spurgeon, and Pearson, Gerald H.J. Emotional Problems of Living. New York: W.W. Norton \& Co. Inc., 1945.

Kalinowsky, I.B., and Hoch, P.H. Shock Treatments and Other Somatic Procedures in Psychiatry. New York: Grune and Stratton, 1946.

Lowrey, Lawson G. Psychiatry for Social Workers. New York: Columbia University Press, 1946.

\section{REPORTS}

Psychiatric Social Work with Insulin-Treated Patients. A report by Minna Field. New York: State Hospitals Press, 1945.

Temporary Commission on State Hospital Problems. Insulin Shock Therapy. New York, 1944

\section{ARTICLES}

Bennett, A.E. "An Evaluation of the Shock Therapies", Psychiatric Quarterly. Vol. XIX. 1945. p. 465.

Bond, E.D. "Continued Follow-up Results in Shock Therapy and in Control Cases." American Journal of Psychiatry. Vol. SCVII. 1941. p. 1024.

Bond, E.D., and Rivers, T.D. "Further Follow-up Results in Insulin Shock Therapy". American Journal of Psychiatry. Vol. XCIX. 1942. p. 201.

Chrzanowski, Gerhard. "Contrasting Responses to Electric Shock Therapy in Clinically Similar Catatonics". Psychiatric Quarterly. Vol. XCIX. 1942. pp. 283-293.

Gralnick, Alexander. "The Carrington Family: A Psychiatric and Social Study Illustrating the Psychosis of Association or Folie A Deux." Psychiatric Quarterly. Vol. XCIX. 1942. pp. 295.

Kalinowsky, I.B. "Electric Convulsion Therapy in Schizophrenia." Lancet. II. 1939. p. 1232. 
Kalinowsky, L.B., and Worthing, H.J. "Results with Electric Convulsive Therapy in Two Hundred Cases of Schizophrenia". Psychiatric Quarterly. Vol. XVII. 1943. pp. 144-153.

Malzberg, Benjamin. "The Outcome of Electroshock Therapy in the New York Civil State Hospitals." Psychiatric Quarterly. Vol. XVII. 1943. pp. $154-163$.

Malzberg, Benjamin. "Increase of Mental Disease". Psychiatric Quarterly. Vol. XVII. 1943. pp. 488-507.

Negrin, J. "Studies on Shock Therapy". Journal of Nervous and Mental Disease. Vol. CI. 1945. p. 15.

Nussbaum, Kurt. "Observation on Electric Shock Therapy". Psychiatric Quarterly. Vol. XVII. 1943. p. 327.

Penrose, L.S., and Marr, W.E. "Results of Shock Therapy Evaluated by Estimating Chances of Patients Remaining in Hospital Without Such Treatment." Journal of Mental Science. Vol. XXCIX. p. 374.

Polatin, Phillip. "Shock Treatment in Schizophrenia". The Family. December, 1945 pp. 283-285.

Polatin, Phillip. "Shock Treatment in Psychiatry". The Family. July, 1946. pp. $174-178$.

Proctor, Lorne D. "Indications for Shock Therapy in Mental IIIness." Digest of Neurology and Psychiatry. Series No. 13. May, 1945. pp. 287-290.

Rennie, Thomas A.C. "Analysis of One Hundred Cases of Schizophrenia with Recovery." Archives of Neurology and Psychiatry. Vol. XIVI. 194l. pp. 197-229.

Rennie, Thomas A.C. "Follow-up Study of 500 Patients with Schizophrenia Admitted to the Hospital from 1913 to 1923." Archives of Neurology and Psychiatry. Vol. XIII. 1942. pp. 877-891.

Reznikoff, Leon. "Indications and Results of Electric Shock Therapy in Mental Disorders". Psychiatric Quarterly. Vol. XVII. pp. 355-57.

Ryerson, Rowena. "Case Work with Psychiatric Patients Treated with Shock Therapy". The Family. December, 1945. pp. 283-287.

Smith, Iauren H., Hastings, Tonald W., and Hughes, Joseph. "Immediate and Follow-up Results of Electroshock Therapy". American Journal of Psychiatry. Vol. C. November, 1943. p. 351 .

Smith, Lauren H., et al. "Electroshock Treatment in the Psychoses." American Journal of Psychiatry. Vol. Y.CVIII. 1942. p. 558. 
Taylor, J.H. "Returns of Schizophrenics Following Shock Therapy" . Disease of the Nervous System. VOI. VI. 1945. p. 28.

Zizowitz, M.N. "Shock Therapy for Insanity". American Mercury. Vol. LXIII. 1945. pp. 467-472. 